\title{
PELATIHAN RANCANG BANGUN ALAT PERAGA PRAKTIKUM FISIKA BAGI GURU-GURU FISIKA SMA
}

\author{
Tatik Juwariyah ${ }^{1)}$, Sigit Pradana ${ }^{2)}$, Yuhani Djaya ${ }^{3)}$, \\ ${ }^{1,2,3)}$ Fakultas Teknik, Universitas Pembangunan Nasional "Veteran" Jakarta \\ e-mail : ${ }^{1)}$ juwariyah_tj@upnvj.ac.id
}

\begin{abstract}
ABSTRAK
Hambatan praktikum fisika di tingkat SMA disebabkan oleh beberapa faktor.Salah satu faktor tersebut adalah masih jarangnya pelatihan penguasaan peralatan laboratorium bagi para guru.Akibatnya kreatifitas guru fisika dalam mempraktekkan konsep fisika yang diajarkan masih rendah sehingga diperlukan pelatihan perancangan alat peraga praktikum fisika.Tujuan kegiatan ini adalah memberikan pelatihan perancangan alat peraga praktikum fisika yang sedang up to date yaitu alat peraga pembangkit listrik energi terbarukan. Alat peraga praktikum pembangkit listrik energi terbarukan yang diberikan pada kegiatan pelatihan ini adalah pembangkit listrik tenaga angin (wind turbine). Pelatihan ini dapat dibagi menjadi dua tahap. Pertama, penjelasan komponen-komponen yang diperlukan dalam merancang alat peraga pembangkit listrik energi angin. Kedua, pengujian alat hasil rancangan yaitu dengan memvariasikan kecepatan angin yang datang pada alat peraga energi angin dan mengukur daya listrik yang dihasilkan. Pada kegiatan pengabdian kepada masyarakat ini para peserta(guru) dilatih merangkai komponen-komponen alat peraga. Namun para guru belum sempat melakukan pengambilan data dan menganalisis data hasil pengujian alat peraga secara mandiri. Namun demikian para guru telah diperagakan cara mengambil data variasi kecepatan angin terhadap daya keluaran. Adanya pelatihan perancangan alat praktikum fisika berupa alat peraga pembangkit listrik energi terbarukan khususnya pembangkit listrik tenaga angin bagi guru-guru fisika diharapkan dapat menjadi salah satu solusi hambatan pelaksanaan praktikum fisika di tingkat SMA.
\end{abstract}

Kata Kunci : teknologi pakan ternak, olahan susu, sapi perah

\section{PENDAHULUAN}

Madrasah Aliyah Miftahul Umam adalah sebuah sekolah islam swasta setingkat SMA didirikan tahun 1978, beralamat di Jl. RS Fatmawati, Gg H. Kamang No 25, Pondok Labu, Cilandak Jakarta Selatan dan beralamat email : ma.miftahul.umam@gmail.com. Status sekolah tersebut Terakreditasi A pada tahun 2010. Sebagaimana disajikan pada Gambar 1 , sekolah tersebut memiliki visi "Berilmu Amalan dan Beramal Ilmiah". Saat ini kepala sekolah MA Miftahul Umam dalah Wahyu Marhendratmo, S.Si.

Hasil wawancara dengan kepala sekolah MA Miftahul Umam setiap jenjang kelas terdiri dari kelas IPA dan IPS sebagaimana sekolah-sekolah SMA lain di wilayah DKI

Jakarta. Jam kegiatan belajar mengajar dilaksanakan mulai pukul 7.30 - 14.30. Dari survey lapangan kegiatan belajar mengajar dilaksanakan di kelas. Dikarenakan tidak adanya ruang praktikum di sekolah ini, semua mata pelajaran disajikan dalam bentuk teori di kelas. Khususnya pada mata pelajaran fisika yang kebetulan diampu oleh kepala sekolah menyatakan bahwa tidak pernah diadakan kegiatan praktikum fisika ataupun kegiatan belajar mengajar fisika dengan pendekatan praktik peraga fenomena fisika.

Berdasarkan analisis situasi yang dipaparkan sebelumnaya ditemukan adanya hambatan pelaksanaan praktik fisika di MA Miftahul Umam Jakarta disebabkan oleh beberapa faktor. Pertama, khususnya di MA Miftahul Umam Jakarta tidak memiliki fasilitas ruang laboratorium fisika. Kedua, materi fisika di SMA cukup padat, tidak sebanding dengan jumlah jam pelajaran yang tersedia sehingga praktik fisika hampir ditiadakan oleh karena keterbatasan waktu. Ketiga, intensitas guru dalam mengikuti pelatihan laboratorium masih rendah sehingga pemahaman guru terhadap konsep serta penggunaan alat-alat praktik fisika cukup rendah.

Hambatan-hambatan pelaksanaan praktik fisika khususnya di kedua SMA/MA tersebut sebenarnya dapat disiasati dengan cara mengadakan kerjasama antara pihak sekolah dan pihak universitas. Lokasi 
Universitas Pembangunan Nasional "Veteran" Jakarta khususnya Fakultas Teknik UPNVJ tidak terlalu jauh dari kedua sekolah tersebut sehingga kerjasama antara kedua pihak sangat diperlukan dalam berbagai bidang.Selain itu, sumbangan kegiatan tri dharma berupa pengabdian kepada masyarakat yang dilakukan oleh dosen seperti mengadakan pendampingan atau pelatihan ke sekolah misalnya pelatihan perancangan alat peraga praktik fisika sangat diperlukan

Berdasarkan situasi yang dipaparkan di bagian sebelumnya ditemukan bahwa alat peraga pembangkit listrik energi terbarukan merupakan salah satu topik alat peraga yang sedang up to date dan perlu disosialisasikan kepada para siswa. Pembangkit listrik energi terbarukan adalah solusi dari masalah semakin menipisnya bahan bakar seperti minyak bumi, batu bara dan gas alam. Pembangkit listrik merupakan terapan dari konsep induksi elektromagnetik yang diajarkan di tingkat SMA. Sehingga alat peraga pembangkit listrik energi terbarukan sangat dibutuhkan guru-guru fisika SMA untuk memperagakan bagaimana konsep fisika khususnya GGL(gaya gerak listrik) induksi elektromagnetik bekerja secara nyata menghasilkan listrik AC.

Hasil survei lapangan di kedua sekolah tersebut memberi kesimpulan bahwa perlu adanya pembekalan ataupun pelatihan bagaimana mengoperasikan sekaligus merakit suatu alat peraga sederhana konsep pembangkit listrik energi terbarukan bagi para guru fisika.Pembekalan atau pelatihan yang dilakukan secara kontinu kepada para guru dapat mengatasi masalah tidak efektifnya kegiatan praktikum fisika.Kegiatan pembekalan atau pelatihan dapat meningkatkan kreatifitas dan ketrampilan para guru fisika yang selama ini cenderung hanya mengajar dengan pendekatan teoritis di kelas. Kreatifitas dan ketrampilan para guru fisika jelas menambah kualitas transfer ilmu kepada para siswa.

\section{TARGET DAN LUARAN}

\section{2.a Target}

Peserta pelatihan yang menjadi target sasaran kegiatan ini adalah para guru fisika SMA. Peserta pelatihan dilatih merangkai model pembangkit listrik energi terbarukan yaitu pembangkit listrik tenaga angin (wind turbine).Peserta juga dilatih menguji coba alat peraga listrik tenaga angin (wind turbine) yaitu pada beberapa variasi kecepatan angin.

\section{2.b Luaran}

Luaran kegiatan Program Pengabdian kepada Masyarakat ini dijelaskan pada Tabel 1 berikut.

Tabel 1. Luaran kegiatan Iptek Bagi Masyarakat

\begin{tabular}{|l|l|l|}
\hline No & Jenis Luaran & $\begin{array}{l}\text { Indikator } \\
\text { capaian }\end{array}$ \\
\hline 1 & $\begin{array}{l}\text { Publikasi ilmiah di } \\
\text { jurnal/prosiding }\end{array}$ & Draft \\
\hline 2 & $\begin{array}{l}\text { Peningkatan pemahaman } \\
\text { dan kualitas masyarakat }\end{array}$ & $\begin{array}{l}\text { ada sertifikat } \\
\text { kegiatan }\end{array}$ \\
\hline 3 & $\begin{array}{l}\text { Jasa, model, rekayasa } \\
\text { sosial,sistem,produk/barang }\end{array}$ & $\begin{array}{l}\text { Produk rancang } \\
\text { bangun alat } \\
\text { peraga }\end{array}$ \\
\hline 4 & Buku ajar & Modul praktik \\
\hline
\end{tabular}

Kegiatan pengabdian kepada masyarakat ini dilakukan dengan beberapa tahapan. Skema tahapan pelaksanaan kegiatan dijelaskan seperti Gambar 1. berikut.

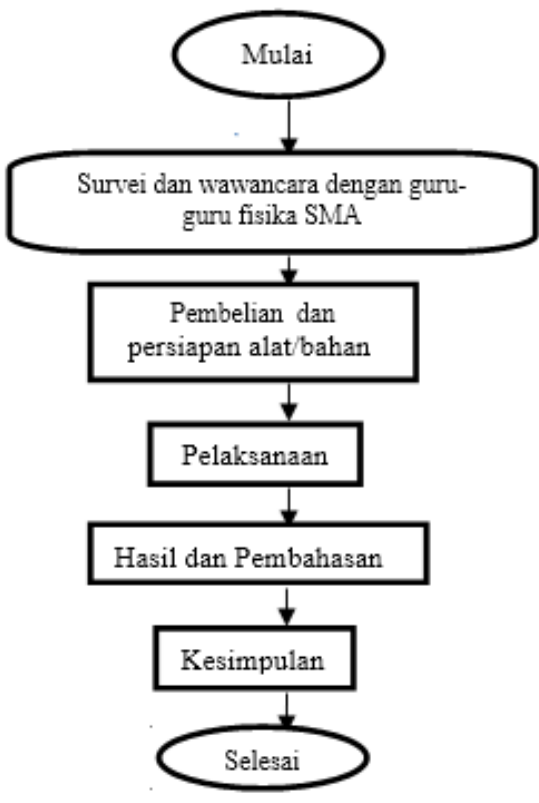

Gambar 1. Diagram alir kegiatan

\section{HASIL DAN PEMBAHASAN}

\subsection{Lokasi Kegiatan}

Kegiatan ini dilaksanakan di Laboratorium Fisika Fakultas Teknik UPN "Veteran" Jakarta dan MA 
Miftahul Umam, Cilandak, Jakarta Selatan seperti tersaji pada Gambar 2.4.2 Peserta Kegiatan

Peserta Kegiatan adalah guru-guru fisika MA Miftahul Umam yaitu guru fisika kelas X, XI,XII.

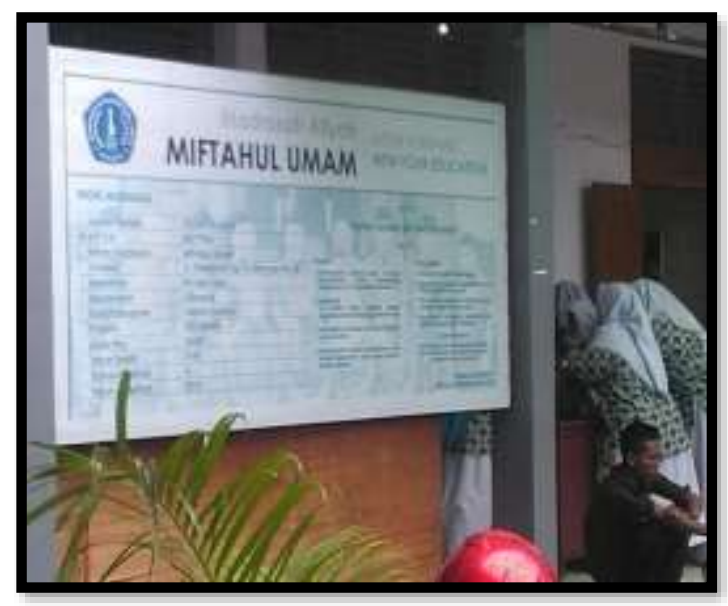

Gambar 2. Lokasi kegiatan PPM

\subsection{Alat dan Bahan yang dipakai}

Alat dan bahan yang digunakan pada pelaksanaan kegiatan pengabdian masyarakat ini adalah sebagai berikut.

1. Proyektor : menjelaskan materi pelatihan

2. Laptop : menjelaskan materi pelatihan

3. Rol Konektor listrik : menghubungkan listrik

4. Kipas angin : untuk menciptakan angin buatan

5. Anemometer : mengukur kecepatan angin

6. Multitester : mengukur arus, voltase keluaran alat peraga

7. Seri alat peraga pembangkit listrik tenaga angin, terdiri atas beberapa bagian utama yaitu : balingbaling (blade), generator, ekor, controller

\subsection{Tahapan - tahapan pelaksanaan kegiatan}

3.3.1. Penjelasan konsep pembangkit listrik tenaga angin (wind turbine).

Energi yang tersedia pada angin adalah energi kinetik dari sebagian besar massa udara yang bergerak diatas permukaan bumi. Sudu turbin angin menerima energi kinetik kemudian mengubahnya ke dalam energi mekanik atau listrik tergantung penggunaan akhir. Efisiensi konversi angin ke bentuk energi lain yang berguna tergantung pada efisiensi dimana rotor berinteraksi dengan aliran angin sebagaimana dijelaskan Mathew (2006). Untuk memperbesar daya keluaran dari turbin maka bisa dengan dua langkah yaitu memperbesar luasan permukaan area sapuan angin $(A)$ dan meningkatkan kecepatan dari angin (v).Menurut Korprasertsak \& Leephakpreeda, (2016) saluran antar guide vane menghambat angin untuk meningkatkan kecepatan angin.

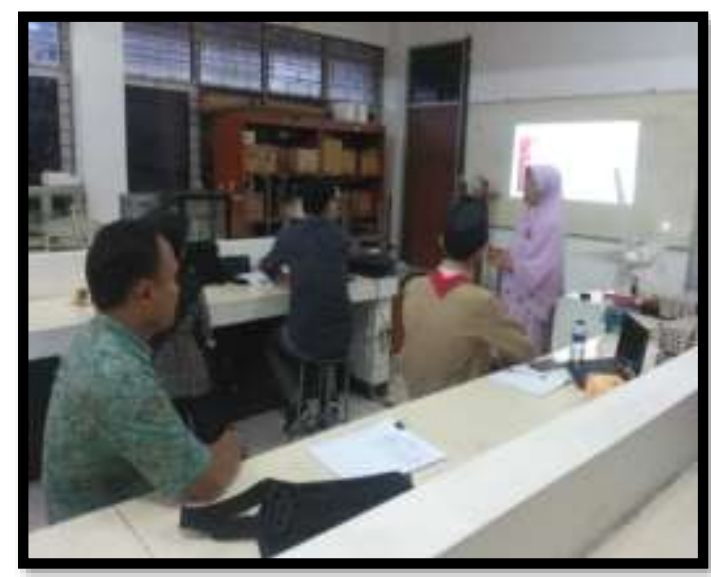

Gambar 3. Penjelasan konsep pembangkit listrik

Daya angin dapat ditulis dengan persamaan sebagai berikut (Korprasertsak \& Leephakpreeda, 2016).

$$
P=\frac{1}{2} \rho A v^{3}
$$

Dimana:

$\mathrm{P}$ : daya mekanik yang dihasilkan rotor (watt) $\rho$ : masa jenis udara $\left(\mathrm{kg} / \mathrm{m}^{3}\right)$

A : luas penampang $\left(\mathrm{m}^{2}\right)$

$v:$ kecepatan aliran udara $(\mathrm{m} / \mathrm{s})$

Daya teoritis yang tersedia pada aliran angin adalah pada persamaan diatas. Sedangkan turbin tidak dapat mengubah daya dari angin secara keseluruhan. Ketika aliran angin melewati turbin, sebagian dari energi kinetiknya ditransfer ke rotor dan udara meninggalkan turbin. Daya aktual yang dihasilkan oleh rotor dipilih sebagai efisiensi dimana energi yag ditransfer dari angin ke rotor berada. Efisiensi ini biasanya dinyatakan sebagai power coefficient $\left(\mathrm{C}_{\mathrm{p}}\right)$. Sehingga, power coefficient rotor dapat didefinisikan sebagai perbandingan antara daya aktual turbin dengan daya yang dihasilkan oleh angin sebagai berikut

$$
C_{p}=\frac{2 P_{T}}{\rho_{a} A_{T} V^{3}}=\frac{P_{T}}{P}
$$

Dimana,

$\mathrm{P}_{\mathrm{T}}$ : daya yang dihasilkan oleh turbin

$\mathrm{P}$ : daya yang dihasilkan oleh angin 
Power coefficient dari turbin bergantung pada beberapa faktor seperti bentuk profil sudu, susunan sudu, setelan dan lain-lain. Secara eksperimen daya keluaran turbin dinyatakan sebagai daya listrik dalam bentuk arus keluaran dan tegangan diukur dengan multimeter. Alih bentuk persamaan (2) dinyatakan sebagai :

$$
P_{T}=C_{p} P
$$

\subsubsection{Penjelasan komponen-komponen alat peraga} pembangkit listrik tenaga angin (wind turbine).

Komponen-komponen alat peraga pembangkit listrik tenaga angin (wind turbine) antara lain :

\section{a.Baling-baling(blade)}

Blade merupakan bagian penting dalam suatu sistem turbin angin sebagai komponen yang berinteraksi langsung dengan angin.Secara umum terdiri dari 2 tipe yaitu horizontal axis wind turbine (HAWT) dan vertical axis wind turbine (VAWT). Kedua tipe ini dapat disesuaikan dengan orang yang ingin mengimplementasikannya dan kemampuannya dalam mewujudkan.Untuk tipe vertikal pembuatannya jauh lebih sulit dibandingkan horizontal dan tergantung pada keterampilan pembuatnya.

\section{b.Generator}

Generator merupakan alat konversi energi mekanik menjadi energi listrik.Generator mengubah torsi (T) dan kecepatan putar rotor yang diterimanya dari blade menjadi nilai tegangan (V) dan arus (I).

\section{c.Ekor}

Ekor turbin angin berfungsi mengarahkan turbin angin menghadap arah angin. Ukuran ekor perlu disesuaikan dengan turbin angin sehingga mampu mendorong badan turbin ke arah angin.

\section{d.Controller}

Controller berperan sebagai alat konversi energi listrik dari AC menjadi DC dan pengatur sistem tegangan masukan yang fluktuatif dari generator untuk distabilkan sebelum disimpan ke baterai.

\section{e.Baterai}

Baterai/aki berperan sebagai media penyimpanan energi listrik. Pada baterai terjadi reaksi elektrokimia charging dan discharging. Proses charging ini bekerja saat baterai berfungsi sebagai beban dan sumber energinya dari generator, sementara itu proses discharging adalah ketika baterai menjadi sumber energi untuk pengisian beban lainnya (misalkan lampu).

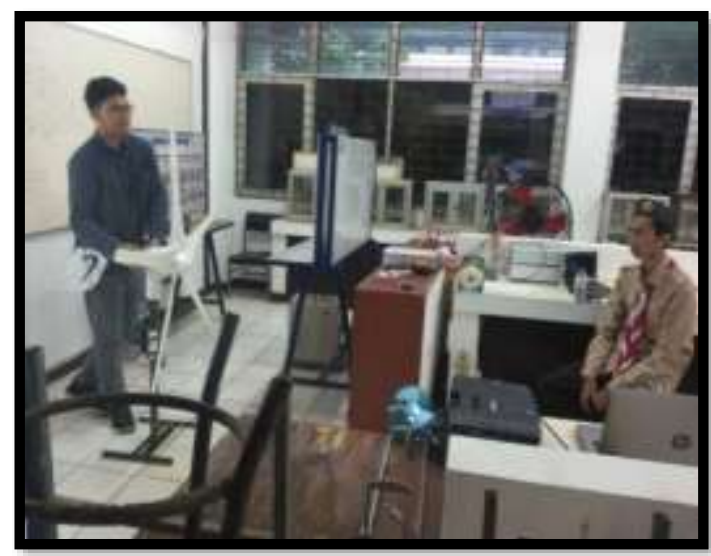

Gambar 4. Penjelasan komponen wind turbine

3.3.3 Praktek merangkai alat peraga pembangkit listrik tenaga angin (wind turbine).

Setelah mendapatkan penjelasan mengenai komponen-komponen alat peraga pembangkit listrik tenaga angin (wind turbine), selanjutnya peserta merangkai komponen-komponen wind turbin.

3.4 Uji coba pengambilan data alat peraga pembangkit listrik tenaga angin (wind turbine).

Alat peraga pembangkit listrik tenaga angin yang berhasil dirakit para peserta selanjutnya dilakukan uji coba pengambilan data. Pengambilan data dilakukan dengan menentukan variasi kecepatan angin di depan alat peraga. Kecepatan angin yang datang diatur dengan memencet tombol kipas angin yang disediakan pada pelatihan seperti Gambar 5.

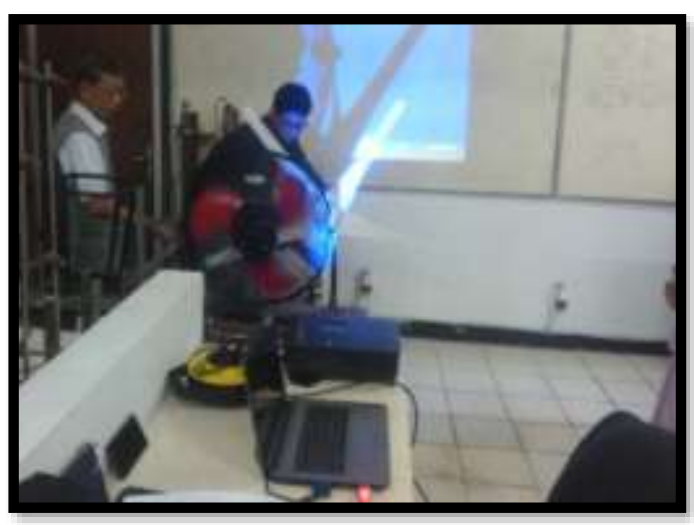

Gambar 5. Uji coba variasi kecepatan angin di depan wind turbine 
Hasil uji coba pengambilan data variasi kecepatan angin yang terukur pada anemometer terhadap daya keluaran alat peraga menunjukkan semakin cepat angin menerpa pembangkit listrik, maka semakin besar arus atau tegangan keluaran seperti tersaji di Gambar 6.

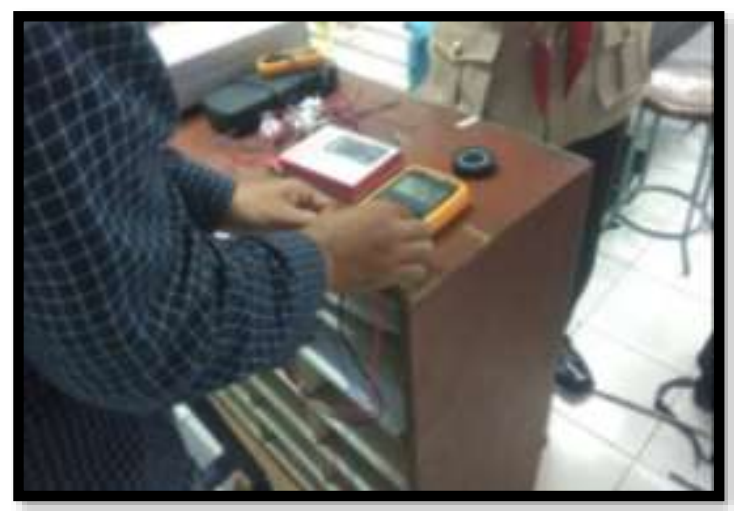

Gambar 6. Arus dan Tegangan keluaran yang dihasilkan wind turbine

Cara memvariasi kecepatan angin yang datang adalah dengan menggeser maju-mundur kipas angin di depan baling-baling turbin sedemikian sehingga diperoleh nilai kecepatan angin yang diinginkan. Setiap nilai kecepatan angin yang terbaca di anemometer dicatat, dan hasil nilai tegangan dan arus keluaran alatperaga juga dicatat seperti tersaji pada Tabel 2.

Berdasarkan persamaan (3) yang menyatakan hubungan antara daya keluaran turbin terhadap daya angin masukan dan dari data uji coba di lapangan diperoleh data-data seperti tersaji pada Tabel 2. Tabel 2 mengasumsikan luas sudu dan kerapatan udara dianggap konstan, sehingga hanya dihitung hubungan kecepatan angin terhadap daya angin berdasarkan persamaan (1).

Tabel 2. Data hasil uji coba wind turbine

\begin{tabular}{|c|c|c|c|c|c|}
\hline $\begin{array}{l}\mathrm{N} \\
\mathrm{O}\end{array}$ & $\begin{array}{l}\text { Kecep } \\
\text { atan } \\
\text { angin } \\
(\mathrm{m} / \mathrm{s})\end{array}$ & $\begin{array}{l}\text { Arus } \\
\text { (A) }\end{array}$ & $\begin{array}{l}\text { Tega } \\
\text { ngan } \\
(\mathrm{V})\end{array}$ & $\begin{array}{l}\mathrm{P}_{\text {angin }} \\
\text { (watt) }\end{array}$ & $\begin{array}{l}\mathrm{P}_{\text {Turbin }} \\
\text { (watt } \\
\text { ) }\end{array}$ \\
\hline 1 & 2,00 & 2,32 & 3,71 & 8,0 & 8,61 \\
\hline 2 & 3,00 & 3,10 & 4,52 & 27,0 & 14,0 \\
\hline 3 & 4,00 & 4,36 & 5,72 & 64,0 & 24,9 \\
\hline 4 & 5,00 & 5,1 & 6,12 & 125 & 31,2 \\
\hline 5 & 6,00 & 5,4 & 6,54 & 216 & 35,3 \\
\hline
\end{tabular}

Dari Gambar 7 diperoleh bahwa perbandingan nilai daya turbin (keluaran) terhadap daya angin (masukan) yang dinyatakan dengan coefisien power sebesar 0,12 atau $12 \%$. Hal ini berarti hanya dua belas persen tenaga dihasilkan oleh turbin. Banyaknya kehilangan tenaga diakibatkan karena munculnya getaran pada gerak turbin sehingga rotor turbin teras panas karea gesekan (terdapat kalor yang hilang ke lingkungan) selain itu terdengan bunyi yang cukup keras dari putaran baling-baling.

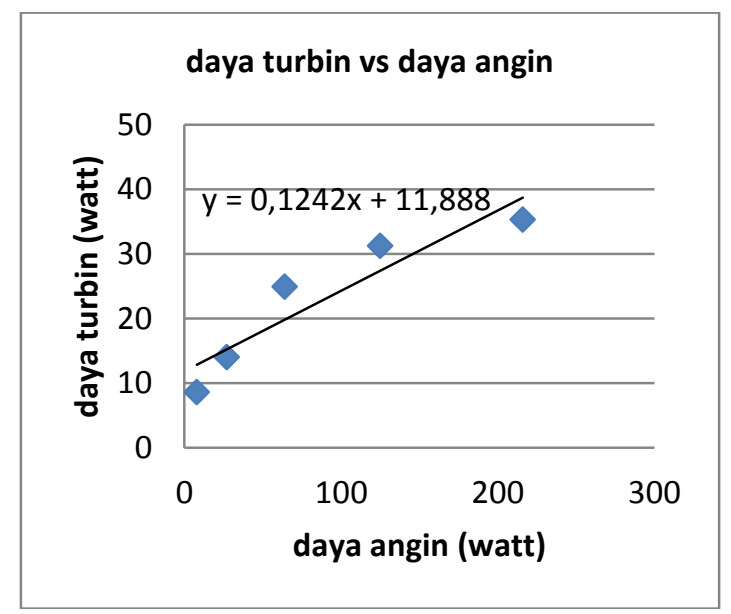

Gambar 7. Grafik daya turbin versus daya angin

\section{KESIMPULAN}

Hasil kegiatan ini adalah rancang bangun alat peraga praktikum fisika berbentuk alat peraga pembangkit listrik energi angin (wind turbine) yang dirangkai oleh para guru fisika SMA. Selain itu juga diperoleh data uji coba alat peraga dengan menguji pada beberapa variasi kecepatan angin. Dari data uji coba diperoleh hasil semakin cepat angin mengenai turbin semakin besar daya turbin dihasilkan. Diperoleh nilai perbandingan daya turbin keluaran terhadap daya angin masukan (coefisien power) sebesar 0,12 atau $12 \%$.

\section{UCAPAN TERIMA KASIH}

Terimakasih kami ucapkan kepada pihak-pihak yang telah berpartisipasi dalam realisasi kegiatan pengabdian kepada masyarakat ini diantaranya : LPPM UPN "Veteran" Jakarta yang telah mendanai kegiatan ini; para peserta kegiatan Bapak/Ibu Guru Fisika MA Miftahul Umam Jakarta dan SMAN 34 Jakarta, dan pihak-pihak lain yang tidak dapat kami 
sebutkan satu persatu atas dukungan dan saran selama kegiatan.

\section{REFERENSI}

Iqlima N.A.D, Prabowo, 2014, Pengembangan Alat Peraga Bndul Matematis untuk Melatih Ketrampilan Proses Siswa pada Materi Gerak Harmonik Sederhana di Kelas XI SMAN 3 Tuban, Jurnal Inovasi Pendidikan Fisika (JIPF), vol 03,No. 02, hal 189-194, ISSN:2302-4496

Riki Purnama, dkk , 2015, Perancangan Alat Peraga Kolektor Surya Pemanas Air Guna Menjelaskan Suhu dan Kalor Pada Kelas X SMA Muhammadiyah Purworejo, Jurnal Radiasi Vol.6 .No. 1, FKIP Universitas Muhammadiyah Purworejo, Purworejo.

Rus Seytaningrum R., 2013, Efektivitas Pelaksanaan Praktikum Fisika Siswa SMA Negeri Kabupaten Purworejo, Jurnal Radiasi, Vol.3.No. 1, FKIP
Universitas Muhammadiyah Purworejo, Purworejo.

Ruzita S., dkk, 2013, Rancang Bangun Miniatur Turbin Angin Pembangkit Listrik Untuk Media Pembelajaran, Jurnal Teknik Mesin Politeknik Negeri Padang, Volume 3 No.2, Padang.

Sudarmadi, 2012, Meningkatkan Kemampuan GuruGuru Fisika SMA/SMK Binaan dalam Membuat Alat Peraga Praktikum Fisika SederhanaMelalui Pendampingan di Kabupaten Kulonprogo, Prosiding Pertemuan Ilmiah XXVI HFI Jateng \& DIY, Purworejo 14 April 2012 ISSN : 08530823 .

Sutrisno, 1986, Elektronika, Teori Dasar dan Penerapannya, Jilid 1, Penerbit ITB, Bandung. Yennita, dkk , 2013, Hambatan Pelaksanaan Praktikum IPA Fisika yang Dihadapi Guru SMP Negeri Di kota Pekanbaru, Jurnal FMIPA FKIP Universitas Riau,Pekanbaru. 